\title{
VISUAL EXPERIMENT
}

\section{Studying antimicrobial-induced morphostructural damage of bacteria by Scanning Electron Microscope}

\author{
Shruti Shukla \\ Department of Food Science and Technology, Yeungnam University, Gyeongsan-Si, \\ Gyeongsanbuk-Do 712 749, Republic of Korea.
}

Correspondence: shruti.shukla15@yahoo.com; Fax: +82-53-810-4662

First Published: 24 October, 2015; Updated version: 1.0

DOI: $10.3329 /$ bjp.v10i4.25427

\section{ABSTRACT}

In this investigation, a scanning electron microscopy (SEM) method was used to examine the morphostructural changes in bacterial cells induced by antimicrobial agents. SEM-based visual approach is referred the study of bacterial cells and their physiological consequences when affected by antibiotics or antibacterial agents permitting the observation of characteristic morphological defects of cell wall, and provides valuable insights into processes involved in bacterial cell death. This experiment visualized various step-by-step techniques used in the slide preparation of bacterial cells treated with specific antimicrobial agent for analyzing the morphological alterations such as increase of cell wall roughness, cell disruption, cell swelling and lysed cell formation due to loss of intracellular material using SEM analysis when compared with untreated normal cells as a control. The SEM approach used in this visual experiment may analyze the antimicrobial effect of any commercially known or new compounds in a very conducive manner.

\section{INTRODUCTION}

Bacterial contamination is increasingly becoming a cause of concern for human health (Martin and Beutin, 2011). A number of reports have indicated that the root cause of bacterial infection might be due to, improper cultivation, and unhygienic handling at critical stages of industrial food production representing some of the most important sources for the entry of virulent and sometimes multidrug-resistant bacterial strains in the food chain (Martin and Beutin, 2011). In order to minimize food degradation by harmful microorganisms and extend the shelf-life of food, legislations allow the application of synthetic antibacterial additives (Guillard et al., 2009). However, excessive use of synthetic additives encourages the emergence of resistant bacteria. Therefore, due to the potential risk with synthetic antibacterial agents, there is a growing interest in the use of natural novel antibiotics or antimicrobials, particularly those that are derived from plant sources.

Although there are various selective culture dependent conventional methods and inhibitory assays such as assessment of zone of inhibition by disc diffusion assay, minimum inhibitory concentration assay, minimum bactericidal concentration assay, and cell viability assay (Bajpai et al., 2010) are available to visualize the inhibitory effect of antibacterial agents, they have remained insufficient to provide detailed information of antibacterial effect on cell morphological structural damage caused by particular antimicrobial agent eventually disrupting cell metabolisms. Therefore, there is a growing need to develop an easy handling and efficient strategy to investigate the morphological cell damage in bacterial cells caused by commercial antibiotics and/or new antimicrobial agents to minimize the bacterial contamination and future thereat of antimicrobial resistance development.

Hence, present study investigates visual demonstration on how to investigate the morphostructural damage in bacterial cells treated with particular antimicrobial agent (antibiotic and/or antimicrobial agent) in terms of its antimicrobial effect against pathogenic bacteria by using step-by-step visualization of scanning electron microscopic (SEM) analysis. 


\section{MATERIALS AND EQIPMENTS}

Disposables

Sterile plastic pipettes

Tips for micropipettes

Sterile Eppendorf tubes $(1.5 \mathrm{~mL})$

Bacterial culture (based on the desired study)

General equipments and glassware

Autoclave to sterilize the necessary materials

Laminar clean bench

Incubator to maintain optimum temperature for bacterial growth

Measuring cylinder $(100 \mathrm{~mL})$

Volumetric flask $(100 \mathrm{~mL})$

Sterilized forceps

Glass slides (size: $25.4 \times 76.2 \mathrm{~mm}$; thickness: 1-1.2 mm)

Glass cutter

Glass beakers $(50 \mathrm{~mL})$

Glass petriplate

Major equipments

Desktop centrifuge

Vortex

Freezer $\left(-70^{\circ} \mathrm{C}\right.$ for storage of prepared slide until further analysis)

Critical point dryer (Hitachi HCP-2)

Precision etching coating system (Hitachi W-1030)

Scanning Electron Microscope (Hitachi S 4100)

\section{REAGENTS AND SOLUTIONS}

\section{Bacterial culture broth}

Sterilized nutrient broth: $100 \mathrm{~mL}$

Bacterial stock: $\quad 100 \mu \mathrm{L}$

\section{Phosphate buffer solution 0.05 M ( $p H$ 7.4)}

Potassium phosphate monobasic (Sigma): $\quad 0.680 \mathrm{~g} / 100 \mathrm{~mL}$ distilled water

Potassium phosphate dibasic (Sigma): $\quad 0.871 \mathrm{~g} / 100 \mathrm{~mL}$ distilled water

Drop wise mix monobasic solution into dibasic solution until $\mathrm{pH}$ reaches to 7.2.

Make up to $100 \mathrm{~mL}$ in a volumetric flask.

\section{Glutaraldehyde (2.5\%)}

Glutaraldehyde:

$2.5 \mathrm{~mL}$

Distilled water:

$97.5 \mathrm{~mL}$

\section{Ethanol (50\%)}

$\begin{array}{ll}\text { Ethanol: } & 50 \mathrm{~mL} \\ \text { Distilled water: } & 50 \mathrm{~mL}\end{array}$




\section{Ethanol (70\%)}

$\begin{array}{ll}\text { Ethanol: } & 70 \mathrm{~mL} \\ \text { Distilled water: } & 30 \mathrm{~mL}\end{array}$

Ethanol (80\%)

Ethanol:

$80 \mathrm{~mL}$

Distilled water:

$20 \mathrm{~mL}$

Ethanol (90\%)

Ethanol:

$90 \mathrm{~mL}$

Distilled water:

$10 \mathrm{~mL}$

Ethanol (95\%)

Ethanol:

$95 \mathrm{~mL}$

Distilled water:

$5 \mathrm{~mL}$

\section{Ethanol (100\%)}

\section{t-Butanol}

\section{VIDEO CLIPS}

Culturing of bacteria

Treatment of bacterial culture by antimicrobials

Sample pre-treatment

Microscopic slide preparation

Critical point drying and ion sputter coating of slides

Scanning Electron Microscopic analysis of coated slides
$2 \min 54 \mathrm{sec}$

$4 \mathrm{~min} 21 \mathrm{sec}$

$4 \mathrm{~min} 23 \mathrm{sec}$

$9 \min 27 \mathrm{sec}$

$5 \min 52 \mathrm{sec}$

$4 \mathrm{~min} 18 \mathrm{sec}$

\section{METHOD}

\section{Preparation of bacterial cell culture}

1. Prepare sterilized nutrient broth in a conical glass flask $(250 \mathrm{~mL})$ for sample treatment as well as for control set.

2. Inoculate $100 \mu \mathrm{L}$ of bacterial stock culture (approximately $10^{7} \mathrm{CFU} / \mathrm{mL}$ ) into the nutrient broth (100 $\mathrm{mL}$ ) under laminar bench.

3. Incubate the inoculated broth in the incubator at $37^{\circ} \mathrm{C}$ for $16-18$ hours.

\section{Inoculation and treatment of antibiotic/antibacterial agent in culture medium}

1. Take out the bacterial culture from incubator and place it to laminar bench.

2. Transfer $900 \mu \mathrm{L}$ of bacterial culture in Eppendorf tubes for sample treatment as well as for control.

2. Inoculate $100 \mu \mathrm{L}$ of the treatment sample, while in case of control, it will be without addition of treatment sample.

3. Vortex it for few 2 seconds to provide it proper mixing.

4. Again place the tube in incubator at $37^{\circ} \mathrm{C}$ for $5-6$ hours.

5. Centrifuge both treatment and control tubes at 3,000-4,000 rpm for $5 \mathrm{~min}$.

6. Discard the supernatant and wash the pellet using $1 \mathrm{~mL}$ of phosphate buffer solution $0.05 \mathrm{M}(\mathrm{pH} 7.4)$.

7. Repeat the process of washing with same buffer and finally collect the pellet of both treatment and control separately. 
[We can check the several different concentrations of treatment samples in order to get an idea of lowest concentrate that can also be effective for damaging morphology of bacterial cells followed by cell death]

\section{Slide preparation for morphological analysis}

1. Make the smear on glass slide using pipettes tip.

2. Cover the smear with $2.5 \%$ glutaraldehyde about $2 \mathrm{~mL}$.

3. Incubate the slide at room temperature for 2 hours.

4. Wash the smear with phosphate buffer solution $(0.05 \mathrm{M})$ for $1 \mathrm{~min}$.

5. Dehydration treatment of smear:
a. $50 \%$ Ethanol for $10 \mathrm{~min}$
b. $70 \%$ Ethanol for $10 \mathrm{~min}$
c. $80 \%$ Ethanol for $10 \mathrm{~min}$
d. $90 \%$ Ethanol for $10 \mathrm{~min}$
e. $95 \%$ Ethanol for $10 \mathrm{~min}$
f. $100 \%$ Ethanol for $10 \mathrm{~min}$

6. Wet the smear with $t$-butanol and incubate the slide at room temperature for 2 hours.

7. Discard $t$-butanol present on smear and add fresh $t$-butanol.

8. Store the slide at $-20^{\circ} \mathrm{C}$ in refrigerator.

\section{Scanning electron microscopic instrumentation and analysis}

1. Perform critical drying to the prepared slides by using liquid and gas $\mathrm{CO}_{2}$ at temperature ranging from $20-40^{\circ} \mathrm{C}$.

2. After drying, mount the slides on 10 or $25 \mathrm{~mm}$ copper cell.

3. Place the slides on coating machine (Hitachi W-1030) to make platinum coating on the slide.

4. Place the coated slide on Field Emission -Scanning electron microscope.

5. Observe the image by setting photo speed, contrast/ brightness and image size.

[Untreated cells must be studied as control (untreated bacteria) to ensure the observed differences at electron microscope between control and the bacterial cells exposed to the antibiotics/ antimicrobial agent]

\section{DISCUSSION}

Around the world, in many healthcare facilities, bacterial pathogens that express multiple resistance mechanisms are becoming the norm, complicating treatment and increasing human morbidity, food poisoning and financial costs. Prudent use of antibacterial agents using at the appropriate dosage and for the appropriate bacterial species is one of the important means of reducing the selective pressure that helps resistant organisms emerge. Here in the present study, SEM visual experiment determined the changes in morphology of the bacteria after treatment with antibiotics/ antimicrobial agent in comparison with control cells. The bacterial cells exposed to antibiotics/ antimicrobial agent showed various phases in the process of cell death which correspond to an intermediate from stage of cell disruption, plasmolysis and partial disappearance of the cytoplasmic membrane. The structure of the outer membrane is apparently unaffected at this stage, however, the cell takes on a deformed morphology, with partial lack of the cytoplasmic membrane. At the final stage of cell disruption, the outer membrane is progressively lost and the cytoplasm tends to spill out of the cell and finally cell death. Influence with the above findings, therefore, in the present study, we provided step-by-step protocol for investigating the morphological cell damage sensitivity or resistant of bacterial species against any antibiotics/ antimicrobial agent using SEM analysis, which will certainly help in other vital aspects to control the widespread of bacterial infection, providing sufficient personnel and resources for infection control in all healthcare facilities. 


\section{REFERENCES}

Bajpai VK, Na M, Kang SC. The role of bioactive substances in controlling foodborne pathogens derived from Metasequoia glyptostroboides Miki ex Hu. Food Chem Toxicol. 2010; 48: 1945-49.

Guillard V, Issoupov V, Redl A, Gontard N. Food preservative content reduction by controlling sorbic acid release from a superficial coating. Innov Food Sci Emerg. 2009; 10: 108-15.

Gupta A, Mahajan S, Sharma R. Evaluation of antimicrobial activity of Curcuma longa rhizome extract against Staphylococcus aureus. Biotechnol Rep. 2015; 6: 51-55.

Martin A, Beutin L. Characteristics of Shiga toxin-producing Escherichia coli from meat and milk products of different origins and association with food producing animals as main contamination sources. Int J Food Microbiol. 2011; 146: 99-104.

\section{PRECAUTIONS}

Incubation temperature and time should be checked for test bacterial species.

Avoid any possible contamination during bacterial growth and inoculation of treatment sample.

Bacterial smear slides must be dipped in $t$-butanol and stored at $-20^{\circ} \mathrm{C}$ in refrigerator until further drying step.

Careful precautions should be taken while cutting the glass slide.

Use of laboratory hand gloves and $70 \%$ ethanol should be maintained on every step throughout the experiment to avoid cross-contamination. 


\section{Your feedback about this paper}

1. Number of times you have read this paper 0

2. Quality of paper
Excellent
Good
Ooderate
Not good

3. Your comments

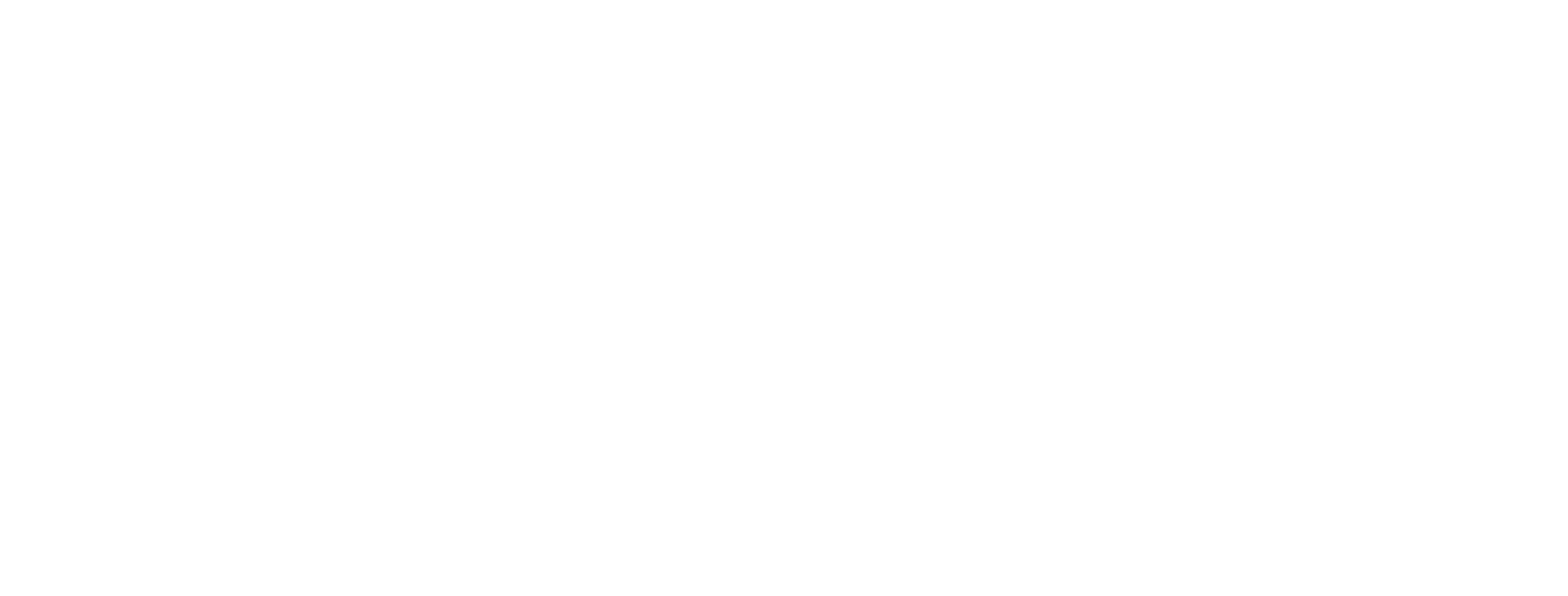

